\title{
A novel optimization method on logistics operation for warehouse \& port enterprises based on game theory
}

\author{
Junyang $\mathrm{Li}^{1}$, Xiaomin Zhu' ${ }^{1}$, Runtong Zhang ${ }^{2^{*}}$ \\ ${ }^{1}$ School of Mechanical, Electronic and Control Engineering, Beïing Jiaotong University (China) \\ ${ }^{2}$ Institute of Information Systems, Beijing Jiaotong University (China) \\ 11121401@bjtu.edu.cn,xmzhu@bjtu.edu.cn,rtzhang@bjtu.edu.cn \\ *: Corresponding author
}

Received: November 2012

Accepted: September 2013

\section{Abstrac:}

Purpose The following investigation aims to deal with the competitive relationship among different warehouses \& ports in the same company.

Design/mathoddogy/approadr In this paper, Game Theory is used in carrying out the optimization model. Genetic Algorithm is used to solve the model.

Findings: Unnecessary competition will rise up if there is little internal communication among different warehouses \& ports in one company. This paper carries out a novel optimization method on warehouse \& port logistics operation model.

Originality/value Warehouse logistics business is a combination of warehousing services and terminal services which is provided by port logistics through the existing port infrastructure on the basis of a port. The newly proposed method can help to optimize logistics operation model for warehouse \& port enterprises effectively. We set Sinotrans Guangdong Company as an example to illustrate the newly proposed method. Finally, according to the case study, this paper gives some responses and suggestions on logistics operation in Sinotrans Guangdong warehouse \& port for its future development.

Keywards: warehouse \& port, logistics operation, optimized model, game theory, genetic algorithm 


\section{Introduction}

Warehouse logistics business is a combination of warehousing services and terminal services which is provided by port logistics through the existing port infrastructure on the basis of a port. Using economic benefit evaluation, researches on general warehouse logistics business always set warehouse \& port as a part of integrated transportation. In fact, the main purpose of warehouse logistics business is to seek for benefit. This kind of seeking will lead to the competition between container orders and transportation ships.

For the warehouse \& port, the larger the storage yard is, the more containers will be attracted. And the more containers attracted, the more help to improve the utilization of the ship load, which can attract more ships to the warehouse yard anchored. The more ships anchored, the more routes will be, and the more routes, the more intensive of the flights. Therefore, it is more conducive for the cargo to choose the ships and shorten delivery options. And then, more containers will be attracted. The status of a virtuous circle is achieved.

\section{Research foundations and related theories}

\subsection{Modern logistics and port logistics}

Modern logistics refers to the whole process of raw materials, finished goods from start to finish and the efficient flow of information. It is a combination of the transportation, storage, handling, processing, finishing, distribution, information, and other aspects. A complete supply chain which can provide multi-functional, integrated and comprehensive services to the users is formed. Modern logistics, as an advanced organization and technology on efficient planning, management and delivery during the period of the product from production to consumption, has become "the third profit source" for companies and society.

Port, an important part and key node of the globe supply chain, is no longer an enterprise that separated from the links of production, trade and transport. It's now becoming the catalyst of the development for economic and trade. Ports can generate a huge radiation function to the surrounding area and the hinterland. More importantly, ports can promote regional or even world economic and trade development.

\subsection{Main theories on port logistics operation mode}

In other countries, the studies of economic issues in port logistics industry are scattered and individual until the 1960s. In most researches, port logistics operation is regarded as a part of shipping economics. And the focus is on the relationships between ports and shipping (Zou, 2007, Chapter 3). Until the 1960s, some issues in a comprehensive study of the port logistics come out (Crainic, Gendreau \& Potvin, 2009; Nijkamp, Reggiani \& Tsang, 2004). However, the real use of economic theory and methods of port logistics business issues are rarely seen. "Port Economics" coauthored by J. O. Jansson and D. Shneerson specially discuss the port logistics 
business issues in application of modern economic theory, especially the pricing issues under the condition of port congestion.

At present, there are many studies on port logistics operation models.

- Port planning theory. Xin Zhang (2008) analyses the conflict between port and ship in the development process of the port. She uses dynamic programming principle on the basis of predicted throughput in raising a new idea, minimum total loss of the throughput capacity to determine a more reasonable scale of the construction of the port.

- Port transportation network optimization decisions. Chuanxu Wang and Liangkui Jiang (2008) optimize the inland transportation network on the regional port. They use bilevel programming model to select inland distribution center and transport network for regional port logistics system and carry out a dual coordination algorithm to solve this model. The result shows that the model and its algorithm are practical and operational.

- Modeling and simulation of logistics systems. Zhao, Tian, Bai and Qian (2009) modeling and simulation of real container reflects the high performance of the professional software WITNESS in terminal logistics operations. This provides a good basis for terminal companies in designing their logistics system.

The focuses of these algorithms are different. Therefore they can solve different kinds of problems. However, these methods lack the adaptability. This paper aims at carrying out an optimization on warehouse \& port logistics operation models based on game theory and accordingly solving the optimized model using Genetic Algorithm.

\section{Optimization model of warehouse \& port logistics operation based on game theory}

\subsection{Assumptions}

The services provided by general warehouse \& port can be regarded as a number of components, for example, container security, service frequency, transit time of containers, as well as service reliability, etc. It may complicate the mathematical programming problem, if all the components above are taken into account. So in order to solve this problem, the following assumptions should be made. There's little difference between the situations based on these assumptions and the real ones. So these assumptions are reasonable.

- Take the selection and use of catchment, transit center, warehouse \& port and target port into consideration integrally.

- The layout of all the catchment, transit center, warehouse \& port and target port has been identified, regardless of location problems. 
- The transportation of containers from the catchment to the target port is road transport, rail transport and sea transport, regardless of other modes of transportation.

- Taking the two-way operations into account, assume that the container can be transported bilaterally between the catchment and the target port.

- The traffic of road transport, rail transport and water transport is limited to the designed capacity in the selected route. There are no security problems in the process of transport and storage.

\subsection{Network model of container transportation}

The catchment has a wide variety of business types and six major types of business can be carried out by the warehouse \& port. Company and the owner of the goods have different views of the business operation type. The company hopes to achieve maximum profits, but the owner hopes to transport the container to the destination as fastest and best as possible with a minimum cost. Therefore, the operation mode of the warehouse $\&$ port logistics varies because of different choices of the company and the owner (Nielsen, 2004). The company and the owner pursue their own interests and make decisions. This dynamic transformation decisionmaking process can be described using game theory. In this decision-making process, the target of each interest group is maximum profit. The behavior of each interest group is described as follows, and their optimization sub-models are built (Friesz, Gottfried \& Morlok, 1986). Assume that the interests of the company and the owner are non-negative.

\section{Carrier's Transport Network Model}

All possible transport programs are given by the carrier. And the traffic volume in each path provided by the owner is already known. The carrier optimizes transport routes in the system with the goal of maximum total profit. Thus, the carrier sub-system determines the optimization model of the transportation mode.

Based on the assumption, the container network transport model of the company can be described as follows.

$$
\text { s.t. }\left\{\begin{array}{cc}
M a \times Z_{1}=R F-T C & \\
Y_{i j}^{z} \geq 0 & \forall i, j, t \\
\sum_{i j}^{z} \leq C_{i}^{z} & \forall i, t \\
\sum_{i} \sum_{j} \sum_{z} f r_{i j}^{z} V^{2} V_{i j}^{z} \geq O D_{r s} & \\
R F=\sum_{i} \sum_{j} f_{i j} \sum_{i} \sum_{s} X_{r i j s} \\
T C=\sum_{i} \sum_{j} \sum_{z} t C_{i j}^{z} V_{i j}^{z}
\end{array}\right.
$$


$R F$ : total transport income; TC: sum of the costs of the company; $Y_{i j}{ }^{t}$ : service frequency of ttype ship in a month between warehouse $\&$ port $i, j$ (decision variable); $C_{i}^{t}$ : the accommodate ability for t-type ships in warehouse \& port $i ; v l^{t}$ : design loading of t-type container ship; $f r_{i j}{ }^{t}$ : real loading rate of t-type container ships between warehouse $\&$ port $i, j ; X_{\text {rijs }}$ : container volume transported from hinterland $r$ to destination $s$ via warehouse \& port $i$, $j$ (decision variable); $f_{i j}$ : cost between warehouse $\&$ port $i, j$; $t c_{i j}{ }^{t}$ : total transport cost of t-type container ships between warehouse \& port $i, j$.

\section{Owner's Transport Network Model}

Owner of the goods select the transport container's starting point and the specific transport path from the possible programs provided by the company in order to satisfy their transportation needs. This kind of user optimum cargo flow pattern defines an O-D collection of transport demand and a general routing model. Owners always concern about their total cost of transport and time loss caused by in-transit and stock containers, and set it as their optimization goal.

Based on the assumption, the container network transport model of the owner can be described as follows.

$$
\begin{aligned}
& \min Z_{2}=I T+R F+T L \\
& s . t .\left\{\begin{array}{cc}
X_{r i j s} \geq 0 & \forall r, i, j, s \\
\sum_{i} \sum_{j} X_{r i j s}=O O r s & \forall r, s \\
\sum_{i} \sum_{j} X_{r j s} \leq \sum f r_{i j}^{2} V^{2} Y_{i j}^{2} & \forall i, j
\end{array}\right. \\
& I T=\sum_{i} \sum_{i} \sum_{j \neq i} \sum_{s=r}\left(c_{r i}+c_{j}\right) X_{r i j s} \\
& T L=\sum_{r} \sum_{i} \sum_{j+i} \sum_{s=r} P_{r s} i_{0} d y_{i j}
\end{aligned}
$$

$I T$ : total cost of hinterland transport; $T L$ : total time loss cost of containers; $C_{r i}$ : transport costs of single-box containers shipped from hinterland $r$ to warehouse $\&$ port $i ; P_{r s}$ : the average time value of containers shipped from hinterland $r$ to destinations; $T L$ : time loss cost of whole process container transport.

\subsection{Game Theory Model}

After building the two sub-models in 3.2, this problem can be regarded as a complete information dynamic non-cooperative game, considering the carrier's route set and the owner's volume choice. Carriers and owners' game process is as follows: carriers carry out a variety of transportation services program, i.e., arranging transportation routes and frequency of services in their own transportation network and obtain optimal strategy by estimating the owner's reaction to various transport programs. 
The dynamic game can be described as follows with extended Game:

- Participants' collection: two interest groups-carriers and owners;

- Sequence of actions: the companies have decision-making priority; owners make their decisions after that;

- Action space: companies-transport route and service frequency (Y); owners-transport volume $(X)$;

- Payment functions: two sub-models in 3.2 .

Figure 1 is a strategy-type game tree.

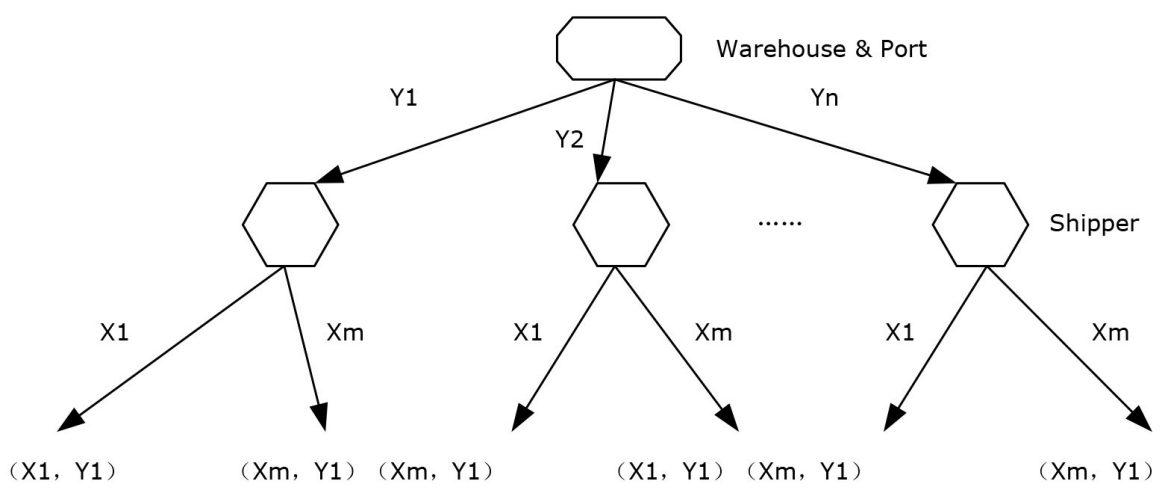

Figure 1. Game Tree

\section{Genetic Algorithm Modeling and Analysis for the Optimization Model}

Section 3 described a complete information dynamic Stackelberg problem (Bakir, 2011; Jungers, Trelat \& Abou-Kandil, 2011). Its decision-making mechanism is like this: the company has decision-making priority. The company selects a route program to their advantage. According to the decision, the company selects a proper transport volume to optimize the objective function which in turn affects the company's final decisions. Therefore, this problem is a joint decision-making problem by two decision-makers who are in grade levels. The company is the leader and the owner is the follower. It is usually described as linear bi-level programming in mathematical programming (Sakawa \& Matsui, 2012).

Simplify the linear bi-level Stackelberg programming problem into a single-stage problem with penalty function using the theory of penalty function. Then a global optimal algorithm is carried out using genetic algorithms (Xuan \& Cheng, 2000, Chapter 5). After Calculation and simplifying, the fitness function of GA can be obtained as follows: 


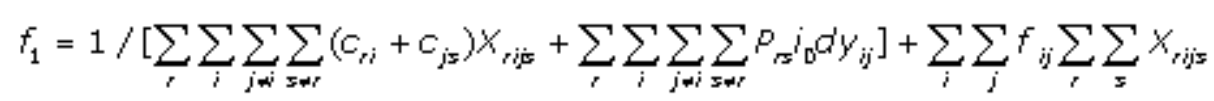

$$
\begin{aligned}
& +(c t)^{2} \sum_{i} \sum_{j} \min \left\{0,1 /\left(\sum_{i} f r_{i j}^{k} v l^{k} Y_{i j}^{k}-\sum_{i} \sum_{s} X_{r j s}\right)\right\}-(c t)^{2} \sum_{i} \sum_{s}\left(\sum_{i} \sum_{j} X_{r i j s}-O D_{r s}\right)^{2} \\
& f_{2}=Z_{1}+(c t)^{2}\left(\varphi_{1}+\varphi_{2}\right)
\end{aligned}
$$

In accordance with the flow chart in Figure 2, genetic algorithm simulation can be started.

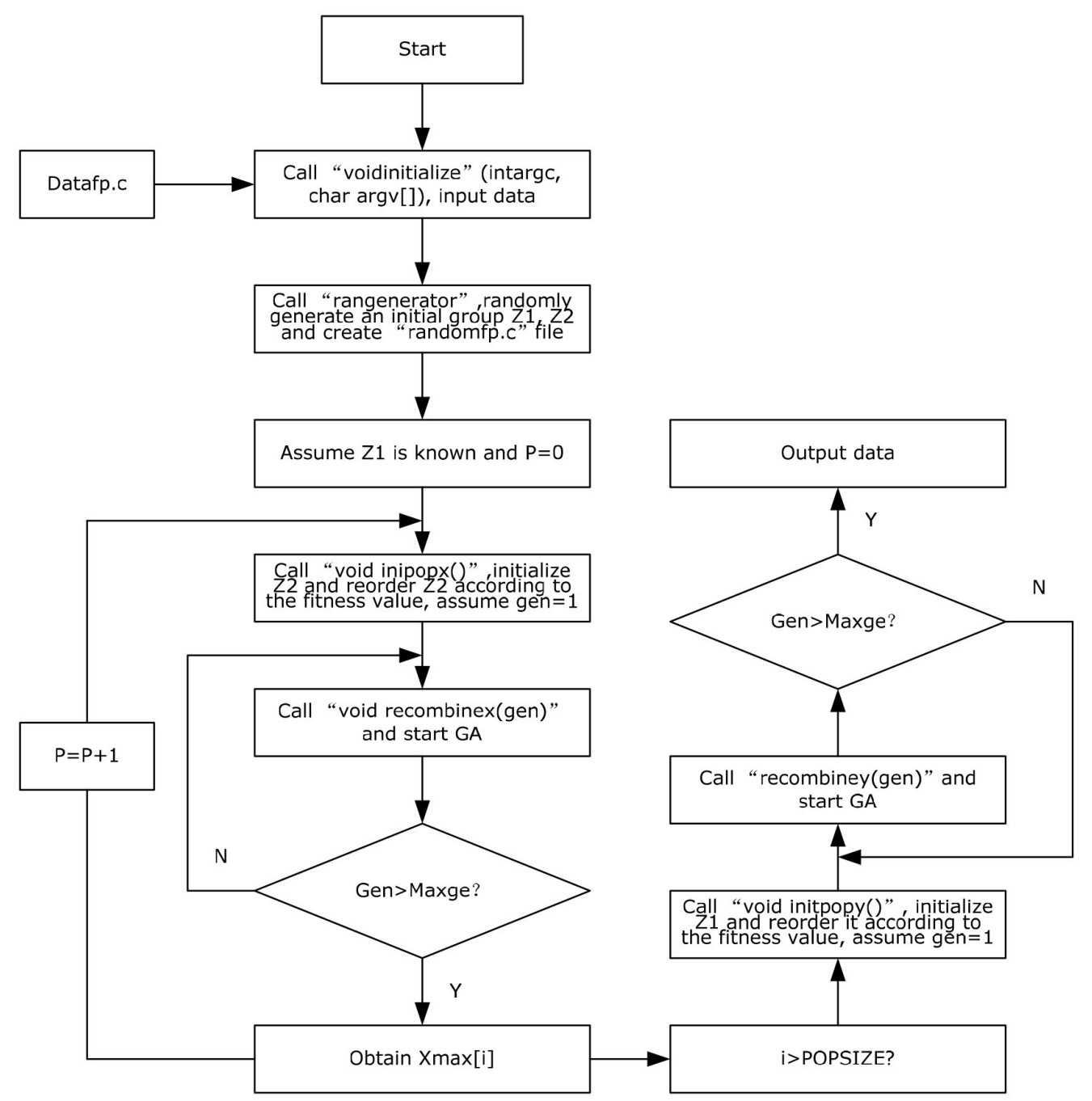

Figure 2. Flow chart of GA

\section{Case Study}

Sinotrans Guangdong Company has eight self-owned container terminal at Huangpu, Dongjiang, Jiaoxin, Zhongshan, Jiangmen, Foshan, Zhanjiang and Guangxi Wuzhou in Guangzhou. Among them, Jiaoxin and Guangxi Wuzhou are newly built warehouse \& ports. Currently, eight ports are operating independently. They just form a loose organization in the name of Sinotrans Guangdong Company. The operation mode is shown in Figure 3. Each port gets orders through the links with the catchment and does business. All ports are lack of fluid exchanging of information and it is unknown which port is most suitable for a certain kind of business. This situation leads to the cost increasing inevitably. There's an implicit competition relationship among the eight ports because of their contentiously seeking for orders to develop 
themselves. Meanwhile, some ports' capacity and traffic are out of proportion, and the phenomenon of repeated construction of the facility leads to waste (Behzad, Moraga \& Chen, 2011). The operation mode of Sinotrans Guangdong Company needs to be adjusted in order to decrease the cost and achieve an overall optimum target to improve the overall competitiveness.

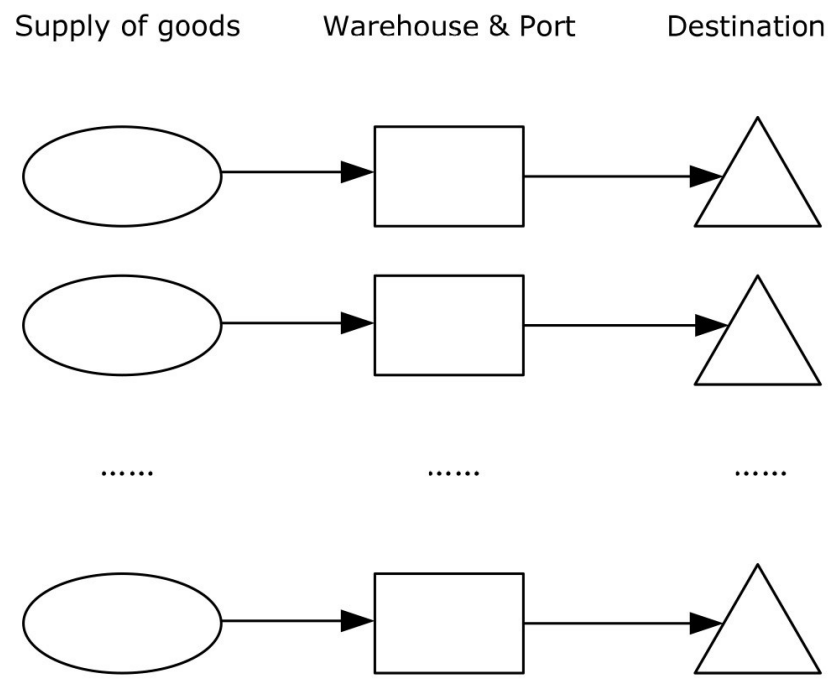

Figure 3. Current logistics operation model

Sinotrans Guangdong Company now lacks of a decision-making tool and a mechanism to exchange information. The owners only aim at the transport of the goods from one place to another when they rarely know the detailed circumstances of the company. So they just select a transportation company according to their experiences or the cost data which is obtained through business negotiations.

The logistics operation mode in the warehouse \& port of Sinotrans Guangdong Company can be optimized according to the process above. We can find that from the 895th generation, the result has already reached the stopping condition of GA. According to the result, flow volume of goods and service frequency for each warehouse $\&$ port can be obtained, shown in Table 1 to Table 8.

\begin{tabular}{|l|c|c|}
\hline \multicolumn{1}{|c|}{$\mathbf{i = 1}$} & Traffic volume (10,000 TEU) & Service frequency(vessel/month) \\
\hline Domestic container & 232.1 & 57 \\
\hline Trade container & 233.81 & 29 \\
\hline Bulk business & 120.93 & 34 \\
\hline Export control storage & 218.98 & 21 \\
\hline Import control storage & 111.43 & 73 \\
\hline Lightering operations & 381.5 & 54 \\
\hline
\end{tabular}

Table 1. Traffic volume and service frequency for Huangpu 


\begin{tabular}{|l|c|c|}
\hline \multicolumn{1}{|c|}{$\mathbf{i = 1}$} & Traffic volume (10,000 TEU) & Service frequency (vessel/month) \\
\hline Domestic container & 43.19 & $\mathbf{2 3}$ \\
\hline Trade container & 25.29 & 38 \\
\hline Bulk business & 39.19 & 38 \\
\hline Export control storage & 28.98 & 9 \\
\hline Import control storage & 119.3 & 11 \\
\hline Lightering operations & 29.42 & 34 \\
\hline
\end{tabular}

Table 2. Traffic volume and service frequency for Dongjiang

\begin{tabular}{|l|c|c|}
\hline \multicolumn{1}{|c|}{$\boldsymbol{i = 1}$} & Traffic volume (10,000 TEU) & Service frequency (vessel/month) \\
\hline Domestic container & 26.23 & 46 \\
\hline Trade container & 28.19 & 12 \\
\hline Bulk business & 27.34 & 36 \\
\hline Export control storage & 112.17 & 39 \\
\hline Import control storage & 43.32 & 102 \\
\hline Lightering operations & 984 & 9 \\
\hline
\end{tabular}

Table 3. Traffic volume and service frequency for Zhongshan

\begin{tabular}{|l|c|c|}
\hline \multicolumn{1}{|c|}{$\mathbf{i = 1}$} & Traffic volume (10,000 TEU) & Service frequency (vessel/month) \\
\hline Domestic container & 43.12 & 74 \\
\hline Trade container & 192.54 & 43 \\
\hline Bulk business & 29.3 & 32 \\
\hline Export control storage & 19.11 & 17 \\
\hline Import control storage & 31.4 & 36 \\
\hline Lightering operations & 28.33 & 7 \\
\hline
\end{tabular}

Table 4. Traffic volume and service frequency for Jiangmen

\begin{tabular}{|l|c|c|}
\hline \multicolumn{1}{|c|}{$\boldsymbol{i = 1}$} & Traffic volume (10,000 TEU) & Service frequency (vessel/month) \\
\hline Domestic container & 454.2 & 132 \\
\hline Trade container & 372.3 & 23 \\
\hline Bulk business & 132.5 & 63 \\
\hline Export control storage & 81.34 & 15 \\
\hline Import control storage & 11.27 & 12 \\
\hline Lightering operations & 184.1 & 47 \\
\hline
\end{tabular}

Table 5. Traffic volume and service frequency for Foshan

\begin{tabular}{|l|c|c|}
\hline \multicolumn{1}{|c|}{$\boldsymbol{i = 1}$} & Traffic volume (10,000 TEU) & Service frequency (vessel/month) \\
\hline Domestic container & 43.2 & $\mathbf{2 4}$ \\
\hline Trade container & 13.81 & 12 \\
\hline Bulk business & 23.2 & 21 \\
\hline Export control storage & 18.18 & 3 \\
\hline Import control storage & 1.27 & 21 \\
\hline Lightering operations & 3.15 & 12 \\
\hline
\end{tabular}

Table 6. Traffic volume and service frequency for Zhanjiang 


\begin{tabular}{|l|c|c|}
\hline \multicolumn{1}{|c|}{$\boldsymbol{i = 1}$} & Traffic volume (10,000 TEU) & Service frequency (vessel/month) \\
\hline Domestic container & 22.1 & 4 \\
\hline Trade container & 12.1 & 24 \\
\hline Bulk business & 48.3 & 16 \\
\hline Export control storage & 49.23 & 25 \\
\hline Import control storage & 73.41 & 9 \\
\hline Lightering operations & 2.8 & 9 \\
\hline
\end{tabular}

Table 7. Traffic volume and service frequency for Jiaoxin

\begin{tabular}{|l|c|c|}
\hline \multicolumn{1}{|c|}{$\boldsymbol{i = 1}$} & Traffic volume (10,000 TEU) & Service frequency (vessel/month) \\
\hline Domestic container & 12.23 & 4 \\
\hline Trade container & 9.1 & 7 \\
\hline Bulk business & 12.3 & 124 \\
\hline Export control storage & 116.3 & 32 \\
\hline Import control storage & 83.4 & 5 \\
\hline Lightering operations & 5.3 & 5 \\
\hline
\end{tabular}

Table 8. Traffic volume and service frequency for Wuzhou

Choose two maximum values of the volume and frequency, and then we can obtain the logistics map, shown in Figure 4. Huangpu and Foshan have the potential to be the hub port when measured by throughput, route number, freight per month and other indicators. The company should theoretically develop Huangpu and Foshan.

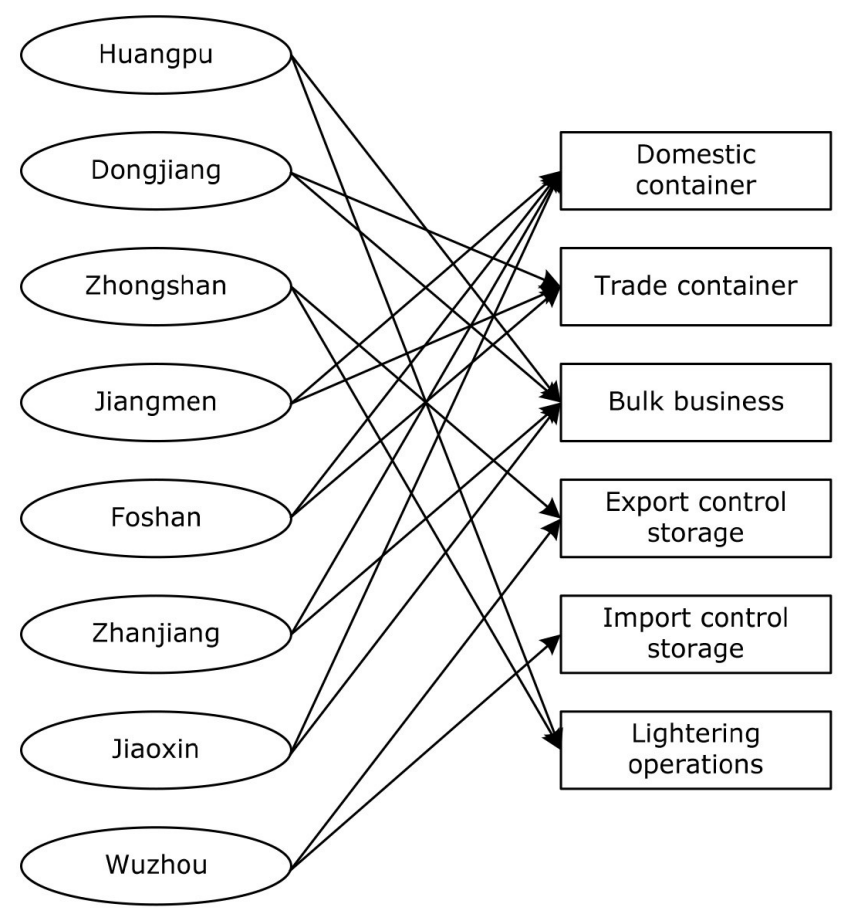

Figure 4. Logistics business of warehouse \& port

According to the results and the current economic situation, we put forward the following recommendations to Sinotrans Guangdong Company warehouse \& port logistics business market positioning for future development. 


\subsection{Develop the expertise advantages respectively}

Although there are many terminals in the Sinotrans Guangdong Company, but most of them are not so large. Through investigation we can learn that storage resources of terminals in the Pearl River Delta have been already in full load operation so that new business can only be leased out currently. Dongjiang borrows Kyrgyzstan container yard for temporary stockpiling when its storage is tense. Zhanjiang's storage is so tense that it cannot carry out additional business for importing corn. Foshan gives up part of the potential market for lack of coastal resources. Yuehua's railway line has not been large-scaled and hasn't formed long-term development ability of warehouse logistics business. Foshan is restricted by the channels, customers and other factors, which causes many large ships not entering. Jiangmen is unable to carry out domestic business for its small terminal yard. At the same time, individual warehouse is idle, for example, Wuzhou has 40,000 square meters space.

According to the calculation results, it shows that some warehouses' logistics traffic doesn't match its execution ability, for example, some warehouses have large logistics traffic, but are short of execution ability. In addition, cost of annual depreciation, energy material and other changes is high and level of maintaining a balanced budget business volume is high, which due to large investment for terminal facilities. Therefore, the warehouse companies should play their own characteristics and focus their own resources to do business which is suitable for them and form their own professional advantages.

\subsection{Integrate the resources among the warehouses $\&$ ports}

On the whole, Sinotrans Guangdong warehouses' layout is carried out with little concern of other warehouses' requirements, which leads to the difficultly in playing integration benefits between adjacent terminals. Integrated logistics services will mainly base on the integration of distributed warehouse resources in the future in order to solve the problems of business imbalance among the terminals, which can improve service efficiency. However, each warehouse node are so disperse that complementary supply, and transit has not been established on the effective integration channel. In recent years, model of "one port, two operating points", which is established by Huangpu and Dongjiang, shows that strengthening the interactive operation between two warehouses not only reduces berthing time, but also balances the terminal utilization. This indicates that Sinotrans Guangdong Company should integrate the resources of every warehouse and collect the overall strength to reduce cost.

\subsection{Explore the hinterlands by water-rail transportation}

The companies' relocation around Pearl River Delta makes the owners' demand for water-rail transportation rise constantly, and once the PRD high-speed rail network is completed, demand for rail transportation will grow by $7 \%$. Based on current economic situation, Sinotrans Guangdong Company must build up a bridge-railway line which can combine the Pan-Pearl 
River Delta hinterland and the Pearl River Delta port in order to consolidate and attract supplement.

\subsection{Improve the level of information}

One of the main reasons that the eight warehouses \& ports of Sinotrans Guangdong Company hasn't formed an entirety is the lack of an information sharing platform for coordination the logistics business operation between each warehouse \& port. To build such a platform, the information level should be fatherly improved so that the information level can reach the same height for all the eight warehouses \& ports.

\section{Conclusions}

Based on the inherent economic laws in water economy, this paper simulates the decisionmaking process of the carrier and the owner by network optimization and game theory. A novel network optimization model is established on the basis of game theory. GA is used to solve the combinatorial optimization problems. Then the suggestion that the warehouse \& port should make adjustment is raised according to the result. Some other advises are also made to the further development of the company.

After the study, the following conclusions can be made:

- The inherent economic laws in water economy must be obeyed in optimizing warehouse \& port logistics business operation;

- The simulation of the decision-making process using game theory in economics totally matches the real container transport process.

- Genetic algorithms can solve complex combinatorial optimization problems quickly and efficiently.

\section{Acknowledgments}

This work is supported by Beijing Natural Science Foundation (Grant No. 4112044) and Research Fund for the Doctoral Program of Higher Education of China (Grant No. 20120009110009). 


\section{References}

Bakir, N.O. (2011). A Stackelberg game model for resource allocation in cargo container security. Annals of Operations Research, 187(1), 5-22.http://dx.doi.org/10.1007/s10479-010-0793-z

Behzad, B., Moraga, R.J., \& Chen, G. (2011). Modelling healthcare internal service supply chains for the analysis of medication delivery errors and amplification effects. Journal of Industrial Engineering and Management, 4(4), 554-576. http://dx.doi.org/10.3926/jiem.201

Crainic, T.G., Gendreau, M., \& Potvin, J.Y. (2009). Intelligent freight-transportation systems: Assessment and the contribution of operations research. Transportation Research Part C-Emerging Technologies, 17(6), 541-557. http://dx.doi.org/ 10.1016/j.trc.2008.07.002

Friesz, T.L., Gottfried, J.A., \& Morlok, E.K. (1986). A sequential shipping-carrier network model for predicting freight flows. Transportation Science, 20(2), 35-41. http://dx.doi.org/10.1287/trsc.20.2.80

Jungers, M., Trelat, E., \& Abou-Kandil, H. (2011). Min-max and min-min stackelberg strategies with closed-loop information structure. Journal of Dynamical and Control Systems, 17(3), 387-425. http://dx.doi.org/10.1007/s10883-011-9123-2

Nielsen, O.A. (2004). Incorporating logistic element sin to freight transport modelling-missing links and shortcuts. Invited key note at International symposium: Transportation and Logistics. Molded University College, Norway, 23(51), 127-132.

Nijkamp, P., Reggiani, A., \& Tsang, W.F. (2004). Comparative modelling of interregional transport flows: Applications to multimodal European freight transport. European Journal of Operational Research, 155(3), 584-602. http://dx.doi.org/10.1016/j.ejor.2003.08.007

Sakawa, M., \& Matsui, T. (2012). Stackelberg solutions for random fuzzy two-level linear programming through possibility-based probability model. Expert Systems with Applications, 39(12), 10898-10903. http://dx.doi.org/10.1016/j.eswa.2012.03.001

Wang, C.X., \& Jiang, L.K. (2008). Inland port transportation network optimization decisions based on bi-level programming. Journal of Industrial Engineering and Engineering Management, 4, 35-42.

Xuan, G.N., \& Cheng, R.W. (2000). Genetic algorithms and engineering design. Beijing, BJ: Science Press.

Zhang, X. (2008). Port berth planning study based on dynamic programming. Journal of Guangdong Ocean University, 28, 45-52. 
Zhao, W., Tian, C.L., Bai, Z.J., \& Qian. F. (2009). Simulation and modelling of internal logistics operating systems in container terminal based on WITNESS. Communications Standardization, 1, 35-42.

Zou, J.S. (2007). Modern port economics. Beijing, BJ: China Communications Press.

Journal of Industrial Engineering and Management, 2013 (www.jiem.org)

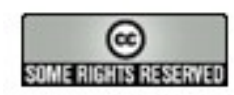

Article's contents are provided on a Attribution-Non Commercial 3.0 Creative commons license. Readers are allowed to copy, distribute and communicate article's contents, provided the author's and Journal of Industrial Engineering and Management's names are included. It must not be used for commercial purposes. To see the complete license contents, please visit http://creativecommons.org/licenses/by-nc/3.0/. 